\title{
Carbon isotopic composition of Neoproterozoic glacial carbonates as a test of paleoceanographic models for snowball
} Earth phenomena

\author{
Martin J. Kennedy Department of Earth Sciences, University of California, Riverside, California 92521, USA \\ Nicholas Christie-Blick Department of Earth and Environmental Sciences and Lamont-Doherty Earth Observatory of Columbia \\ University, Palisades, New York 10964-8000, USA \\ Anthony R. Prave School of Geography and Geosciences, University of St. Andrews, Fife KY16 9AL, UK
}

\begin{abstract}
Consistently positive carbon isotopic values were obtained from in situ peloids, ooids, and stromatolitic carbonate within Neoproterozoic glacial successions in northern Namibia, central Australia, and the North American Cordillera. Because positive values continue upward into the immediately overlying postglacial cap carbonates, the negative isotopic excursions widely observed in those carbonate rocks require an explanation that involves a short-term perturbation of the global carbon cycle during deglaciation. The data do not support the ecological consequences of complete coverage of the glacial ocean with sea ice, as predicted in the 1998 snowball Earth hypothesis of P.F. Hoffman et al. In the snowball Earth hypothesis, the postglacial cap carbonates and associated $-5 \%$ negative carbon isotopic excursions represent the physical record of $\mathrm{CO}_{2}$ transfer from the high- $p \mathrm{CO}_{2}$ snowball atmosphere $(\sim 0.12$ bar $)$ to the sedimentary reservoir via silicate weathering in the snowball aftermath. Stratigraphic timing constraints on cap carbonates imply weathering rates of $\sim 1000$ times preglacial levels to be consistent with the hypothesis. The absence of $\mathrm{Sr}$ isotopic variation between glacial and postglacial deposits and calculations of maximum weathering rates do not support a post-snowball weathering event as the origin for cap carbonates and associated isotopic excursions.
\end{abstract}

Keywords: Neoproterozoic, paleoclimate, carbon cycle, carbonates, glaciation, isotopes.

\section{INTRODUCTION}

Geologic and paleomagnetic evidence in Neoproterozoic sedimentary rocks for low-latitude continental ice sheets is generally accepted (Sohl et al., 1999) and suggests climatic extremes that are unrivaled in Earth history. These deposits differ from otherwise comparable rocks of Phanerozoic age in that the end of glaciation is marked by thin, laterally persistent carbonate caps that are associated with some of the largest known negative excursions in $\delta^{13} \mathrm{C}$ (as low as $\sim-5 \%$; Kaufman et al., 1993; Kennedy et al., 1998). Various models have been proposed to account for these phenomena, including the overturn of a stagnant glacial ocean (Kaufman et al., 1993) and massive postglacial release of methane by destabilization of permafrost gas hydrates (Kennedy et al., 2001). The possibility that the negative carbon isotopic excursions encompass synglacial as well as postglacial strata led Hoffman et al. (1998) to a third model, a modification of the snowball Earth hypothesis of Kirschvink (1992). Hoffman et al. reasoned that such long-lived excursions would require the protracted shutdown of marine ecosystems. This extreme oceanographic condition was attributed to complete coverage of the ocean surface with ice, with attendant effects on Earth's carbon cycle providing an explanation for both cap carbonates and their carbon isotopic excursions.

Here we focus on evidence that observed carbon isotopic excursions are fundamentally postglacial rather than synglacial in origin; and that, contrary to a first-order expectation of the snowball Earth hypothesis, cap carbonates cannot represent the stratigraphic record of greatly enhanced postglacial weathering.

\section{SNOWBALL EARTH HYPOTHESIS}

In the snowball Earth hypothesis of Hoffman et al. (1998), a rapidly cooling climate led to a runaway albedo effect and to the complete coverage of the ocean by ice, thereby isolating the ocean from the atmosphere. The combination of extreme cold and thick sea ice is inferred to have effectively shut down the hydrologic cycle, chemical weathering, marine autotrophic activity, and organic carbon burial, turning off the sinks for volcanic $\mathrm{CO}_{2}$ and rapidly ( $\sim 100$ k.y.) driving the carbon isotopic composition of the ocean to a near-mantle value of $-5 \%$ o (Kump, 1991). Buildup of atmospheric $\mathrm{CO}_{2}$ to $\sim 0.12$ bar over $<10$ m.y. (depending on rates of $\mathrm{CO}_{2}$ outgassing) through the snowball event was ultimately sufficient to overcome the albedo effect, with catastrophic melting of both sea ice and glacial ice over a span as short as several hundred years. Subsequent reequilibration between the $\mathrm{CO}_{2}$ rich atmosphere and an ocean occurred via enhanced rates of continental weathering and $\mathrm{CO}_{2}$ drawdown.

According to the Hoffman et al. (1998) hypothesis, cap carbonates and their associated negative carbon isotopic excursions are the predictable consequence of a massive alkalinity flux resulting from rapid post-snowball weathering. Unlike the modern ocean, surface marine carbon isotopic values would have been determined by the mantle value of the larger atmospheric $\mathrm{CO}_{2}$ pool (hydration of $\mathrm{CO}_{2}$ during transfer from the vapor to the liquid phase would include a $+8 \%$ o Rayleigh fractionation). Decreasing carbon isotopic values up section within the cap carbonates reflect a combination of drawdown of $\mathrm{CO}_{2}$ through silicate weathering and dominance of surface marine values by a progressively more ${ }^{13} \mathrm{C}$-depleted atmospheric reservoir. Values of $\delta^{13} \mathrm{C}$ would have continued to decline until the slowing influence of $\mathrm{CO}_{2}$ drawdown matched the background influence of the biological pump, which drives marine values in a positive direction with the burial of ${ }^{12} \mathrm{C}$-rich organic material. Because Rayleigh distillation represents the single mechanism capable of driving isotopic values negative in the snowball Earth scenario, the isotopic minimum records the end of postsnowball enhanced weathering and the drawdown of anomalous atmospheric $\mathrm{CO}_{2}$. The top of the cap carbonate provides an additional constraint on the end of the weathering event by signifying a reduced flux of weathering-related alkalinity.

\section{PREDICTIONS AND TESTS}

The snowball Earth hypothesis leads to testable corollaries with respect to both carbon and strontium isotopes. The persistence of negative carbon isotopic values through the snowball event was inferred by Hoffman et al. (1998) on the basis of a negative isotopic trend documented in carbonate rocks beneath a Neoproterozoic subglacial karst unconformity in the southern Congo craton (Ghaub Formation; see Fig. 1B). In the absence of isotopic data from primary synglacial carbonates, this assumption is worth scrutiny for two reasons. First, a fall to negative values beneath the unconformity may be subject to geochemical alteration or erosional truncation of the isotopic record. Because of this uncertainty, it is problematic to select a value that is representative of the following millions of years of ocean history, es- 


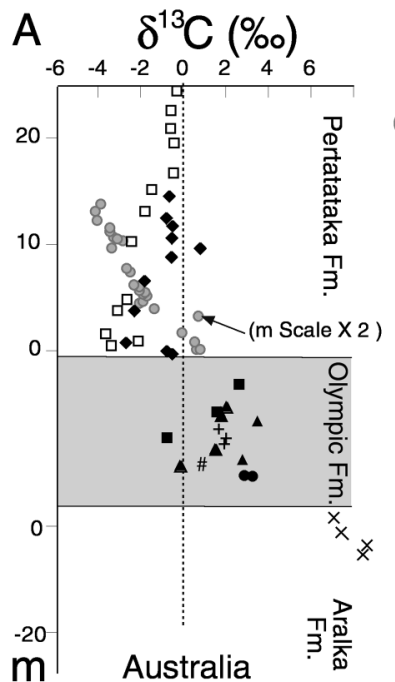

B

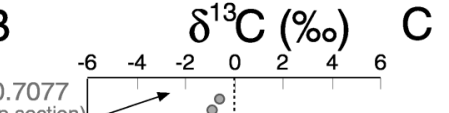

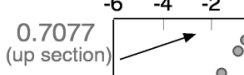

\begin{tabular}{r|c:c}
0.7079 & 8 & $\frac{3}{0}$ \\
20 & 0 & $\frac{\Phi}{\mathbb{D}}$ \\
0 & 0 & $\frac{\Phi}{0}$ \\
0 & 3
\end{tabular}

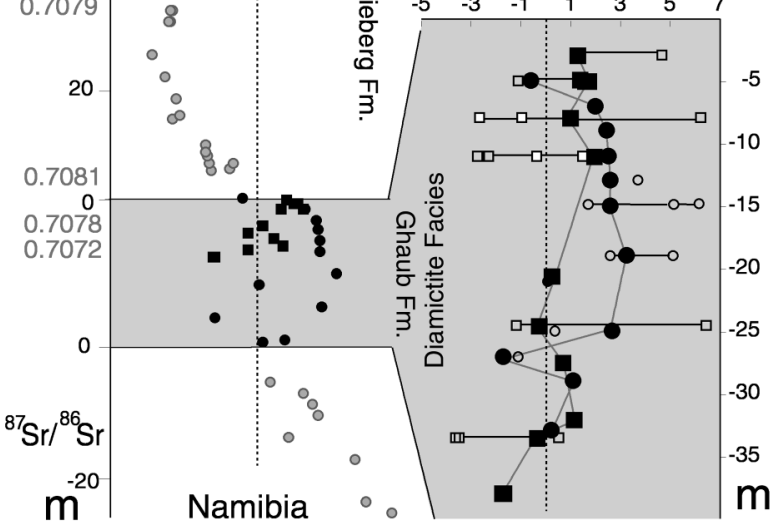

$\delta^{13} \mathrm{C} \%$

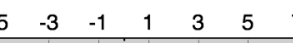

Namibia

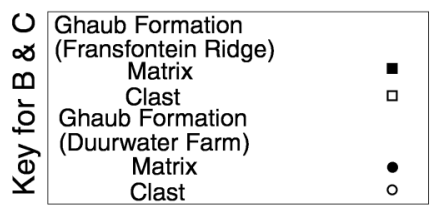

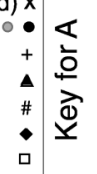

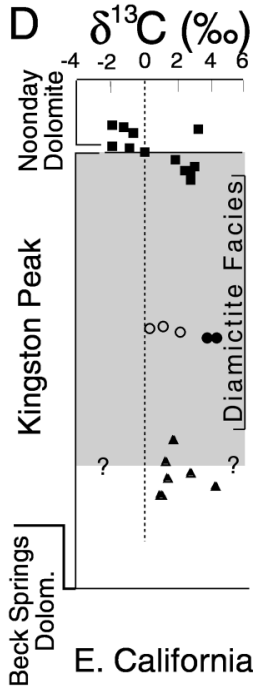

\begin{tabular}{|ll} 
Wildrose/Noonday \\
Kingston Peak Fm. \\
(Beck Springs Canyon) \\
Dolomicrite \\
Oolitic grainstone \\
Virgin Spring limestone \\
$\quad$ (Tucker, 1986)
\end{tabular}
Aralka Formation (Ringwood Homestead) $x$ Olympic Formation (Mount Capitor)

Olympic Formation (Larrier Bore)

Olympic Formation (Hijinx Syncline)

Olympic Formation (Olympic Bore)

Pertatataka Formation (Cleary Creek)

Pertatataka Formation (Hale River)

Figure 1. Carbon isotopic data from preglacial, glacial, and postglacial cap carbonate rocks in northeastern Amadeus basin, central Australia (A), southern Congo Craton, Namibia (B and C), and eastern California (D). No time relationship or correlation within or between glacial intervals is implied other than relative stratigraphic position at single localities and whether carbonate samples were obtained from base, middle, or top of glacial successions. Gray symbols and numbers in A (Mount Capitor) and B (Fransfontein Ridge) indicate data reported from Kennedy et al. (1998). Additional geochemical and location information is available from GSA Data Repository (see text footnote 1). Detail of glacial interval (Ghaub Formation, C) shows two sections with laminated dolomicrite compared to clasts (lonestones). Horizontal lines indicate range of isotopic values within seven clasts. Vertical thickness scale for Fransfontein Ridge and Mount Capitor (gray circles) sections is double that shown in C and A, respectively. Data shown in D are from three intervals in glaciogenic Kingston Peak Formation and postglacial Noonday Dolomite, including ooid grainstone from middle of Kingston Peak, and bedded dolomicrite from transition into Noonday Dolomite (Wildrose Diamictite of Prave, 1999). Data and stratigraphic relations for dolomicrite and oncolitic dolomite in Virgin Spring limestone are from Tucker (1986).

pecially given the change in paleoceanographic conditions from an icefree ocean to an ice-covered ocean that this surface is purported to represent. Second, the linkage of negative isotopic values between preglacial and postglacial intervals is logical only if the controlling mechanism is the same. Since the hypothesis relates the negative carbon isotopic values beneath the glacial rocks to a reduced biological pump and those above the glacial rocks to high fractional burial of carbonate carbon and Rayleigh distillation, the basis for assigning a negative isotopic value to the glacial interval itself seems ad hoc. For these reasons, an obvious test is to investigate the carbon isotopic composition of the ocean during the time of glaciation.

The hypothesis also predicts marked changes in the relative contribution of hydrothermal inputs and continental weathering to the ${ }^{87} \mathrm{Sr} /$ ${ }^{86} \mathrm{Sr}$ ratio of seawater. This ratio ought to have approached the exceedingly low value of 0.7035 after a prolonged interval of greatly diminished weathering. Then it ought to have risen sharply in the immediate aftermath of the snowball event as a result of intense silicate weathering (crustal values $<0.7135$; e.g., Jacobsen and Kaufman, 1999). Although dependent in detail on the bulk composition of crustal rocks being weathered, the radiogenic strontium flux should scale with the rate of silicate weathering needed to draw down the anomalous atmospheric $\mathrm{CO}_{2}$ and supply alkalinity sufficient to account for the mass of rapidly deposited cap carbonate.

The cap carbonate is localized within the transgressive part of the stratigraphy (Kennedy, 1996; Hoffman et al., 1998), and it represents a span that is comparable to, or shorter than, the interval of glacialeustatic rise. In the Quaternary, the time scale of sea-level rise was on the order of $\sim 10$ k.y., but in the snowball scenario it is suggested to have been much more rapid (Hoffman et al., 1998). The relatively short duration of the weathering event implied by this conservative stratigraphic constraint on the cap carbonate $(\sim 10 \mathrm{k} . \mathrm{y}$.) compared to the long buildup of atmospheric $\mathrm{CO}_{2}$ asserted for the snowball period $(<10$ m.y.) means that a 1000 -fold increase in the rate of silicate weathering compared with the preglacial steady-state rate is needed to consume the $\mathrm{CO}_{2}$ stored in the atmosphere. A comparable increase in the radiogenic strontium flux is implied.

\section{SAMPLING GLACIAL CARBONATE ROCKS}

We looked for the predicted isotopic signature in carbonate deposits within three well-known Neoproterozoic successions of glacial and postglacial deposits. Although carbonate rocks are uncommon in Phanerozoic glacial successions, owing to the environmental stress on carbonate-secreting organisms, they are common in Proterozoic counterparts, presumably reflecting the dominance of more environmentally tolerant microbial processes. In order to capture representative marine carbon isotopic values, samples of primary precipitates were obtained from predominantly marine basins on the Congo, Australian, and North American cratons ${ }^{1}$. Samples were collected throughout the glacial and postglacial successions in both Sturtian (ca. $750 \mathrm{Ma}$ ) and Marinoan

${ }^{1}$ GSA Data Repository item 2001130, Sample location, $\delta^{13} \mathrm{C}, \delta^{18} \mathrm{O}$, and lithology data, is available on request from Documents Secretary, GSA, P.O Box 9140, Boulder, CO 80301, editing@geosociety.org, or at www. geosociety.org/pubs/ft2001.htm. 
(ca. $600 \mathrm{Ma}$ ) intervals. Carbonate rocks with evidence for a lacustrine origin (e.g., varves; positive $\delta^{18} \mathrm{O}$ values associated with hydrologically closed lakes, or interstratification with fluvial deposits; Fairchild, 1993) were not considered, and although a lacustrine setting for isolated samples cannot be ruled out, the overall facies association favors a marine origin in each example. Studies of Neoproterozoic carbonate rocks within glacial intervals indicate that some are composed of rock flour and lithic debris (Fairchild, 1993). This component is recognizable by its extremely fine grain size $(<2 \mu \mathrm{m})$ or isotopic covariation with clasts (Hoffman et al., 1998). Here, we focus on primary precipitates such as stromatolites, ooids, and peloids (delicate agglomerations of microcrystalline cement of likely microbial origin; Chafetz, 1986). These textures provide a record of seawater composition, as in any marine environment (Tucker, 1986; Fairchild, 1993). Samples were collected from discrete (2- to 4-m-thick) intervals of laterally continuous carbonate interbedded with glaciogenic facies as well as from cap carbonates immediately overlying glacial deposits.

\section{Southern Congo Craton, Namibia}

The Neoproterozoic succession exposed along the southern margin of the Congo craton is a thick, long-lived carbonate platform that houses two distinct glacial intervals (Chuos and Ghaub formations), each with a cap carbonate. Three lines of evidence support a primary marine origin for some carbonate beds within the Ghaub Formation. (1) Petrographic analysis of micritic intervals reveals the presence of peloidal aggregates with a fine-grained $(>10 \mu \mathrm{m})$ clotted fabric similar to the overlying cap carbonate. Preservation of such fragile textures during glacial transport is exceedingly unlikely, nor do they resemble the petrographic description of rock flour (Fairchild, 1993). (2) Isotopic values within laminated peloidal-micritic carbonate that is interbedded with carbonate-clast diamictite increase systematically toward the top of the section (Fig. 1C). This variation is reproducible in a second section $15 \mathrm{~km}$ away. (3) In contrast, lonestones in associated diamictite show no isotopic trend, and they have a broad variation in $\delta^{13} \mathrm{C}$ of as much as $9 \%$ within a single hand sample (Fig. 1C). However, obvious localized areas of tectonic deformation and textural homogenization show little carbon isotopic variation in either clasts or matrix, supporting a detrital origin or diagenetic modification of isotopic values, as suggested by Hoffman et al. (1998).

Strontium isotopic values from exceptionally well preserved (Mn/ $\mathrm{Sr}<1, \mathrm{Sr}>200 \mathrm{ppm}, \delta^{18} \mathrm{O}>-8 \%$ ) samples within these same glacial and postglacial carbonate deposits (presented in Kennedy et al., 1998) show limited variability, from 0.7072 within glacial carbonates to 0.7077 several hundred meters above the glacial interval. A similar strontium isotopic value of 0.7072 was reported from a likely correlative cap carbonate unit in the Mackenzie Mountains, Canada, by Narbonne et al. (1994).

\section{Central Australia}

Intertidal and subtidal carbonate rocks up to $50 \mathrm{~m}$ thick are present throughout the Marinoan (ca. $600 \mathrm{Ma}$ ) glaciogenic Olympic Formation in the northeastern Amadeus Basin of central Australia (Field, 1991; Freeman et al., 1991). Discrete, laterally persistent intervals of stromatolitic, oolitic, and oncolitic dolomite and dolomicrite overlie, underlie, and in places are interbedded with boulder conglomerate that regionally shows a glacial affinity (Field, 1991; Freeman et al., 1991). Intraglacial carbonate samples were collected from four areas. Although the relative stratigraphic position at different locations is poorly constrained, the isotopic values are consistently positive (Fig. 1A).

Samples were also collected at Mount Capitor from an anomalously thick $(30 \mathrm{~m})$ expanded cap carbonate interval deposited in a proximal position relative to the paleobasin margin (circles in Fig. 1A). This thicker section provides a more complete geochemical record for the initial stages of postglacial transgression. Near the base, $\delta^{13} \mathrm{C}$ val- ues are low and positive $(\sim 2.0 \%)$; upward, they decrease steadily to $<-4 \%$, as is common in the condensed cap facies. Carbon isotopic values from the Cleary Creek and Hale River localities (diamonds and squares in Fig. 1A) are positive within the glacial interval. They fall to $\sim-3 \%$ within the cap carbonate and recover over $20 \mathrm{~m}$ to positive $\delta^{13} \mathrm{C}$ values immediately above the cap carbonate in limestone event beds isolated in siltstone.

\section{North American Cordillera}

In the Death Valley region, California, oolitic-oncolitic and dolomicritic carbonate interbeds are present within the glaciogenic Kingston Peak Formation in the Black Mountains (Tucker, 1986) and Kingston Range, and at the top of the Wildrose Diamictite in the Ibex Hills (Fig. 1D). The Virgin Spring limestone, at the base of a diamictite unit within the Kingston Peak Formation, is composed of oolitic-oncolitic grainstones (Tucker, 1986). These samples show a range of $\delta^{13} \mathrm{C}$ values from $+1 \%$ o to $+4.3 \%$ o (Tucker, 1986). A stratigraphically higher interval of oolitic and laminated dolomicrite, also interbedded with glaciogenic rocks in the Kingston Range (overlain and underlain by several hundred meters of diamictite), shows a range of values from $+3.8 \%$ o to $+4.4 \%$ in oolitic grainstone and from $+0.4 \%$ o to $+2.2 \%$ in dolomicrite (Fig. 1D).

Regionally, the glaciogenic rocks are overlain by the Noonday Dolomite, a locally thick, pure dolomite showing many of the distinctive lithofacies that cap carbonates share globally (Cloud et al., 1974; Prave, 1999). The upper glaciogenic interval (Wildrose Diamictite) is concordantly and possibly conformably overlain by the Noonday Dolomite (Prave, 1999). In the Ibex Hills, discrete dolomicritic beds are present toward the top of the Wildrose Diamictite, and they increase in abundance toward the Noonday contact. Isotopic values decline from $+4 \%$ o to $+2 \%$ o within these dolomicritic beds, and positive values are present near the base of the Noonday Dolomite, falling to negative values $(\sim-3 \%$ ) several meters up section (Fig. 1D). As in Australia and Namibia, glacial, late glacial, and early postglacial carbonate rocks are thus characterized by positive isotopic values that fall to negative values only above the base of the cap carbonate.

\section{DISCUSSION}

The snowball hypothesis of Hoffman et al. (1998) attempts to account for three phenomena peculiar to Neoproterozoic glaciation. These are (1) an inferred negative excursion that Hoffman et al. thought persisted through each glacial interval and attributed to the shutdown of marine ecosystems; (2) widespread deposition of carbonate during deglaciation (cap carbonates) resulting from the transfer of $2.5 \times 10^{20}$ $\mathrm{g}$ of carbon from the atmospheric to the sedimentary carbonate reservoir; and (3) a negative carbon isotopic excursion within the cap carbonate attributed to progressive drawdown of the heavier carbon isotope from the dominating atmospheric carbon reservoir.

The best examples of marine carbonate precipitated during glacial intervals in all three basins show positive carbon isotopic values of $\sim 3 \%$ o (Fig. 1). Positive to very slightly negative isotopic values continue into the base of the cap carbonate, where they become progressively more negative up section. A return toward positive values is observed within tens of meters above the cap carbonate. These data are inconsistent with the snowball Earth hypothesis, as it was originally framed, and do not require a prolonged shutdown of the biological pump during either the Sturtian or Marinoan glacial events.

The cap carbonate is an unlikely physical record of the transfer of $\mathrm{C}$ from the atmosphere to the sedimentary reservoir. The 1000-fold increase in weathering rate needed to transfer $2.5 \times 10^{20} \mathrm{~g}$ of $\mathrm{C}$ from the atmosphere (via silicate weathering) to the ocean is several orders of magnitude too high. A calculation using maximum rates of continental runoff and rivers saturated with $\mathrm{CaCO}_{3}$ in equilibrium with an atmospheric $p \mathrm{CO}_{2}$ of 0.1 bar (300 present atmospheric level) suggests 
that weathering rates could have been no more than 50 times the present rate (L. Kump, 2001, personal commun.). Across the range of weathering environments on Earth today (including soil environments with high $p \mathrm{CO}_{2}$ or additional plant organic acids, and tropical settings) only a tenfold variation in weathering rates of plutonic rocks is observed (Berner and Berner, 1996). No evidence of enhanced weathering rates is apparent in Neoproterozoic Sr isotopic data, which should record a significant signal if the rate of silicate weathering rose even tenfold.

Buffering of the strontium isotopic signal by carbonate weathering and dissolution provides one possible explanation for the lack of $\mathrm{Sr}$ isotopic variation (Hoffman et al., 1998). This would require a carbonate to silicate weathering rate ratio of $>9: 1$ within river water to buffer a crustal weathering signal of 0.7135 to a value of 0.7080 (assuming ${ }^{87} \mathrm{Sr} /{ }^{86} \mathrm{Sr}$ of 0.7075 for preglacial carbonate rocks). Such high rates of carbonate weathering would act to extend the time necessary to draw atmospheric $\mathrm{CO}_{2}$ down through silicate weathering because the energy necessary for weathering is conserved and carbonate weathering has no net effect on atmospheric $\mathrm{CO}_{2}$ concentrations. A 9:1 carbonate to silicate weathering represents an additional source of ${ }^{13} \mathrm{C}$ enriched bicarbonate in the ocean-atmosphere system as preglacial carbonates are weathered. Precipitation of this carbonate in the ocean, and return of comparatively heavy $\mathrm{CO}_{2}$ to the atmosphere (as well as biological pumping) provide a feedback counteracting the ${ }^{13} \mathrm{C}$ distillation effects of silicate weathering on the atmospheric carbon isotopic composition. In the snowball Earth scenario, $\delta^{13} \mathrm{C}$ values within the cap carbonate would be driven in a positive upward trend if the values of weathered carbonate exceeded $0.5 \%$ and a carbonate:silicate weathering ratio of 9:1 was maintained. Since carbon isotopic values of $+5 \%$ o to $+10 \%$ are typical for the preglacial rocks, it becomes difficult to accommodate both strontium and carbon isotopic data simultaneously in the snowball Earth scenario.

Partial or complete equilibration of atmospheric $\mathrm{CO}_{2}$ with the oceanic reservoir through cracks in the sea ice (a soft snowball solution) would raise similar problems for carbonate buffering in a modified snowball Earth hypothesis. The 0.12 bar $\mathrm{CO}_{2}$ atmosphere suggested by Hoffman et al. (1998) would require mole for mole carbonate dissolution (with a $\delta^{13} \mathrm{C}$ of $\sim 5 \%$ o to $10 \%$ ) to maintain carbonate ion saturation in the oceans, a condition needed to explain precipitation of synglacial and immediately postglacial carbonate deposits. Oceanatmosphere equilibration would also result in a greater proportion of carbon distributed in the ocean than in the atmosphere owing to carbonate buffering (although the ratio of carbon in the ocean to the atmosphere would be less for a 0.12 bar $\mathrm{CO}_{2}$ atmosphere than the modern value of $\sim 60: 1$ ). This would greatly increase the time needed for volcanic outgassing, require a significantly greater amount of $\mathrm{CO}_{2}$ removal during post-snowball weathering, result in appreciably thicker cap carbonates, and limit any influence that the atmosphere might have on marine $\delta^{13} \mathrm{C}$ values.

These findings suggest that the principal phenomena the snowball Earth hypothesis was created to explain are either not well established or do not agree with the model in detail. They suggest that significant revision of the snowball Earth model is necessary or that other currently proposed models that better fit the scale and timing of these phenomena be more closely scrutinized.

\section{ACKNOWLEDGMENTS}

We thank Lou Derry, Ian Fairchild, Paul Hoffman, Sören Jensen, Lee Kump, Jean Lynch-Stieglitz, and Linda Sohl for their contributions toward this paper and helpful conversations, and K.-H. Hoffmann for samples. The research on which the paper is based was supported by National Science Foundation grant EAR 94-18294. Lamont-Doherty Earth Observatory contribution 6244.

\section{REFERENCES CITED}

Berner, E.K., and Berner, R.A., 1996, Global environment: Water, air, and geochemical cycles: Englewood Cliffs, New Jersey, Prentice-Hall, 376 p.

Chafetz, H.S., 1986, Marine peloids: A product of bacterially induced precipitation of calcite: Journal of Sedimentary Petrology, v. 56, p. 812-817.

Cloud, P., Wright, L.A., Williams, E.G., Diehl, P., and Walter, M.R., 1974, Giant stromatolites and associated vertical tubes from the upper Proterozoic Noonday Dolomite, Death Valley region, eastern California: Geological Society of America Bulletin, v. 85, p. 1869-1882.

Fairchild, I.J., 1993, Balmy shores and icy wastes: The paradox of carbonates associated with glacial deposits in Neoproterozoic times: Sedimentology Review, v. 1, p. 1-16.

Field, B.D., 1991, Paralic and periglacial facies and contemporaneous deformation of the Late Proterozoic Olympic Formation, Pioneer Sandstone and Gaylad Sandstone, Amadeus basin, central Australia, in Korsch, R.J., and Kennard, J.M., eds., Geological and geophysical studies in the Amadeus basin, central Australia: Australia Bureau of Mineral Resources, Geology and Geophysics, Bulletin 236, p. 127-136.

Freeman, M.J., Oaks, R.Q., and Shaw, R.D., 1991, Stratigraphy of the Late Proterozoic Gaylad Sandstone, northeastern Amadeus basin, and recognition of an underlying regional unconformity, in Korsch, R.J., and Kennard, J.M., eds., Geological and geophysical studies in the Amadeus basin, central Australia: Australia Bureau of Mineral Resources, Geology and Geophysics, Bulletin 236, p. 137-154.

Hoffman, P.F., Kaufman, A.J., Halverson, G.P., and Schrag, D.P., 1998, A Neoproterozoic snowball Earth: Science, v. 281, p. 1342-1346.

Jacobsen, S.B., and Kaufman, A.J., 1999, The Sr, C and O isotopic evolution of Neoproterozoic seawater: Chemical Geology, v. 161, p. 37-57.

Kaufman, A.J., Jacobsen, S.B., and Knoll, A.H., 1993, The Vendian record of $\mathrm{Sr}$ and $\mathrm{C}$ isotopic variations in seawater: Implications for tectonics and paleoclimate: Earth and Planetary Science Letters, v. 120, p. 409-430.

Kennedy, M.J., 1996, Stratigraphy, sedimentology, and isotopic geochemistry of Australian Neoproterozoic postglacial cap dolostones: Deglaciation, $\delta^{13} \mathrm{C}$ excursions, and carbonate precipitation: Journal of Sedimentary Research, v. 66, p. 1050-1064.

Kennedy, M.J., Runnegar, B., Prave, A.R., Hoffmann, K.-H., and Arthur, M.A., 1998, Two or four Neoproterozoic glaciations?: Geology, v. 26, p. 1059-1063.

Kennedy, M.J., Christie-Blick, N., and Sohl, L.E., 2001, Are Proterozoic cap carbonates and isotopic excursions a record of gas hydrate destabilization following Earth's coldest intervals?: Geology, v. 29, p. 443-446.

Kirschvink, J.L., 1992, Late Proterozoic low-latitude global glaciation: The snowball Earth, in Schopf, J.W., and Klein, C., eds., The Proterozoic biosphere: A multidisciplinary study: Cambridge, UK, Cambridge University Press, p. 51-52.

Kump, L.R., 1991, Interpreting carbon-isotope excursions: Strangelove oceans: Geology, v. 19, p. 299-302.

Narbonne, G.M., Kaufman, A.J., and Knoll, A.H., 1994, Integrated chemostratigraphy and biostratigraphy of the upper Windermere Supergroup, northwestern Canada: Implications for Neoproterozoic correlations and the early evolution of animals: Geological Society of America Bulletin, v. 106, p. 1281-1292.

Prave, A.R., 1999, Two diamictites, two cap carbonates, two $\delta^{13} \mathrm{C}$ excursions, two rifts: The Neoproterozoic Kingston Peak Formation, Death Valley, California: Geology, v. 27, p. 339-342.

Sohl, L.E., Christie-Blick, N., and Kent, D.V., 1999, Paleomagnetic polarity reversals in Marinoan (ca. $600 \mathrm{Ma}$ ) glacial deposits of Australia: Implications for the duration of low-latitude glaciation in Neoproterozoic time: Geological Society of America Bulletin, v. 111, p. 1120-1139.

Tucker, M.E., 1986, Formerly aragonitic limestones associated with tillites in the Late Proterozoic of Death Valley, California: Journal of Sedimentary Petrology, v. 56, p. 818-830.

Manuscript received May 1, 2001

Revised manuscript received August 7, 2001

Manuscript accepted August 23, 2001

Printed in USA 